\title{
The Legal Pluralism in Law Education in Indonesia
}

\author{
Rahmat bin Mohamad ${ }^{1 *}$, and I Wayan Rideng ${ }^{2}$ \\ 1. Universiti Teknologi MARA UiTM), Malaysia General of the Asian-African Legal Consultative Organization \\ 2. Universitas Warmadewa, Denpasar-Bali, Indonesia \\ *rmohamad@aalco.int
}

Published: 25/02/2021

How to cite:

D, Dato., Mohamad, b, R., Rideng, I, W. 2021. The Legal Pluralism in Law Education in Indonesia. Sociological Jurisprudence Journal. Volume 4 Issue 1. Page 1 - 5. https://doi.org/10.22225/scj.4.1.2635.1-5

\begin{abstract}
This paper aims to analyze the practice of legal pluralism in Indonesia. A decentralized approach policy enables the growth and the development of various legal systems. By the prevailing of the pluralism of legal system apparently also raises the problem in its application. But in reality, various living legal systems can co-exist. The method applied is based on normative study, with qualitative approach. The result shows that the legal system that pluralism is very influential on the development of education, including law education. Law education in Indonesia is also influenced by the history of Indonesia. The new pattern of law education in Indonesia can only lead people to an obedience and legal compliance. Legal education is not an independent thing, but it is related to social issues. So it has implications for the many violations of law and the emergence of criminal acts. This shows the level of legal awareness of the community is still low. Then it will also affect the legal culture and law enforcement in a country.
\end{abstract}

Keywords: law pluralism, law education, Indonesia

\section{INTRODUCTION}

The application of government system in Indonesia greatly influences the pattern of the legal system. In the era of reformation after almost the regime of 32 years in power, which marked the economic crisis occurred turmoil and national disintegration, finally opened the open the tap of democracy and then turned the point into a country based on decentralization This implies the imposition, not only regulates and grants autonomous rights to the regions (provinces, districts and cities) to carry out their respective governments, while also recognizing and respecting local government units, preferential or special government and acknowledge, respect, andhonor the unity of indigenous peoples and their traditional rights.

The application of centralized into decentralization from the central government to the regions is driven by cultural diversity and society in every region in the form of autonomy after decentralization, thus providing opportunities for legal pluralism to grow and develop in the realm of the legal system of the Unitary State of the Republic of Indonesia. And now the fact in the reality of legal life in Indonesia, there are various legal systems that coexist; customary law, Islamic law, civil law and common law. This is evident from the enactment of local customary law that existed before the independence of Indonesia. This situation is still used in the stages of national development planning, including in the development of education. Customary law is ingrained in Indonesian society. So that sometimes it clashes with the problem and the provisions of national law. It also influences the emergence and birth of "special" status areas such as Aceh Province which is caused by the strong influence of Islamic law. Then it is known as the civil law system, which is largely a feature of national law and the procedure of law in Indonesia, as the consequence of the concordanceprinciple. The development of globalization prompted Indonesia to 
engage in international relations through trade and economic relations with some developed countries, affecting the common law system of law to enter Indonesia.

Though there are no specific regulations that affirm the entity of the legal system that must be applied in Indonesia, but the reality indicates there are several legal systems that have been applied in Indonesia. Thus, the approach of legal pluralism in the formation of national law and the introduction of the law becomes very important in this context of law education.

Law education in Indonesia is also influenced by the history of the Indonesian nation. It starts from the colonial era to the reform era. The law education system is one of the important elements in society. It touches almost every aspect of life. Communities come into contact with the law not only through elements relating to law enforcement (police, prosecutors, judges and advocates), but the law also touches the economy or business area. Even to personal aspects such as marriage, divorce and inheritance. In this regard, the plural legal system will be correlated with education, especially law education. Law education is not an independent one, but will be related to other social problems. It can have an effect on the legal culture, which is then closely related to law enforcement.

\section{DISCUSSION}

\section{The Conceptualization of Legal Pluralism}

The study of legal pluralism is not the domain of new studies in Indonesia. Legal pluralism exists as a critique of centralism and positivism in the application of law to the people. There are several ways to understand legal pluralism. First, legal pluralism explains the relation of various legal systems that work in society. Second, legal pluralism maps the various laws that exist in a social field. Third, explaining relationships, adaptations, and competitions among the legal system. fourth, legal pluralism exposes people's choice to use certain laws when in conflict. From these four perspectives and many other points of view, we can briefly say that legal pluralism is a reality in people's lives (Wahyuni, 2013) Likewise, borrowing the phrasefrom Brian Z. Tamanaha, legal pluralism is everywhere. on the facts and the potential for mutual tension to create uncertainty. This uncertain(Tamanaho, 2012). This expression confirms that in the social area of diversity the normative system is a necessity. However, the interesting thing about legal pluralism lies not only in the diversity of the normative system, but ty becomes one of the weak points that are "attacked" from legal pluralism, although this is not entirely true because the central issue of potential conflict is the asymmetrical relation of the normative system.

In this regard, John Griffiths expressed the concept of weak pluralism and strong pluralism. (Griffiths, 1986) Legal pluralism is referred to as weak legal pluralism when the state recognizes the presence of an element of another legal system outside the state law, but such non-state legal systems are subject to their enforceability under state law. Meanwhile, strong legal pluralism is present when the state recognizes the existence of non-state law and the legal system has the same capacity of enforcement with state law.

This outlook of those both make the analysis of the weaknesses of legal pluralism. When the imbalance of power dominance among the exponents of the various legal systems remains sustainable, then legal pluralism may be a myth, and the creation of legal uncertainty is not impossible if legal pluralism opens the confessional space for any other legal system outside the law of the country without any clear limitations.

\section{The Concept of Law Education.}

The Law Education System is one of the important elements in society. It touches almost every aspect of life. Communities come into contact with the law not only through elements relating to law enforcement (police, prosecutors, judges and advocates), but the law also touches private territory. Law education is not separated from the history of the nation's journey. It appears to be in effect as the phases, namely; colonial era, old order era, new order and reformation. In the reformation era it leads to progressive education. According to Satjipto Rahardjo which stated that progressive legal education is the opposite of legal education of status quo because of the unresponsiveness of the law to fundamental changes in Indonesia. Law is run dogmatically and is not sensitive to the transition process that is being experienced by Indonesia. (Raharjo, 2010). However, Hikmahanto Juwana stated that progressive law 
education is just a discourse and not implemented yet (Juwana, 2010).

Today the law education pattern has changed, is no longer conventional but has been adjusted to the development of science and technology. So legal information can be easier access to everyone and can be more useful. Legal education has entered the stage of e-learning is the stage of learning legal education through electronic media. But this condition does not escape the occurrence of survival, misuse of information and technology with only "cut and paste" without mentioning the source is plagiarism and illegal. If this is done continuously, it will affect the culture of the community, so it does not emphasize the law education to the community.

\section{Legal Pluralism in The Indonesian Context.}

As it has been mentioned above, legal pluralism can be stated to be the answer to the shortcomings encountered in the view of the national legal system in Indonesia which tend to be centralistic. This can be seen from the existence of policies and provisions on some legislation that contains the idea of legal pluralism in it. Such as provisions on the recognition of the rights of customary law communities and ulayat lands. Not only at the national level but also at the local level, local regulations have emerged that attempt to recognize or integrate legal diversity at the local level along with the enactment of regional autonomy and special autonomy. Publication of customary law community law in Bali on Pakraman (customary) Village, local sharia law, qanun in Aceh, and establishment of customary institutions recognized as media for customary dispute resolution.

When examined at a glance, it can be regarded as an effort to renew the law in accommodating the normative diversity in the society. But in reality it sometimes becomes a dilemma, under conditions of weak legal pluralism in the view of Griffiths above. This is because the existence of adat (customary) law is very dependent on state law (positive law). In practice, customary law which is as customs when it is enacted is not fully in accordance with that formulated by state law. This condition is not much different with the existence of customary institutions, in an effort to solve the conflict / conflict in the community, the results are difficult to apply even not often countered by the judiciary. Another case with the sharia law, which in some areas of the local regulations invite strong rejection by the people in the area concerned. Because the provisions in these local regulations are contrary to the provisions of hierarchy of laws that must be aligned, even at a certain point the regulation is considered contrary to human rights.

From the description, about the weakness and criticism of legal pluralism that opens the opportunity for conflict of norms that finally led to legal uncertainty which is an important principle in law enforcement. Law enforcement can also be said is not something that stands alone, because it has links with other social issues of society. In addition, criticism as well as substantial questions about legal pluralism that emerged from the above exposure, its relation to legal education. How to relate to the legal culture of society as well as its relationship with lawenforcements. Because so farthe society in the order of obedience and compliance only, but not at the level of legal awareness.

\section{Legal Pluralism in Law Education in Indonesia}

Legal pluralism does not immediately solve social problems. However, legal pluralism is present to provide a new understanding to legal practitioners, legislators and the wider community, that besides state law there are other legal systems that exist in society and the legal system interacts with state law and even compete with each other. (Lidwina Inge Nurtjahyo). In addition, legal pluralism provides an explanation for the fact that social order is not part of the regularity of state law. The centralistic view holds that the only institution that plays the role of social order is the state through the laws established and set by the state. In reality, there are many other 'powers' that do not come from the state. Among them there are customary law, religious law, customs, trade agreements across the nation and etc. These forces have the same ability to regulate the actions of the people who are bound in them, sometimes even members or communities in the community prefer to obey the rules established by the group rather than the rule of state law.

This condition cannot be excluded from the existence of law as a value system as well as a subsystem of true social systems describe that the das sein and das sollen laws are sometimes not easy to meet even often contrary to the appropriate legal behavior of society. This is not separate from non-juridical factors 
that live and develop that one of them is a legal culture. Culture as a product of society is very diverse and different not only society one with the other so that the result of social levels in the environment. In connection with this, Lawrence M Friedman, mentions; A legal system in actual operation is a complex organism in which structure, substance, and culture interact. (Friedman, 1975). In this context, its legal culture must support the enforcement of the law. Legal awareness, according to him, is closely related to the legal culture of his society. In other words, that the level of legal awareness of high or low society can be seen in the legal culture, if the legal culture tends to positive, proactive to the ideals of the law of society has a high legal awareness.

The purpose and function of law in implementation are often not as expected. This is because it is influenced by many factors, both from within the legal system and outside the legal system affecting the workings of the law. On the other hand, sometimes the community develops a culture that is not conducive in supporting the enforcement of the law. So the essence of the system as a regularity is only a myth that occurs precisely the conflict in the legal system because each component, element, sub system has a fragile contribution to law enforcement. Soerjono Soekanto, put forward several factors that influence law enforcement, namely; legal factors, law enforcers, facilities and infrastructure, community factors, and cultural factors (Soekanto: 1985).

Thus, it is no exaggeration to say that legal pluralism is still or is needed in this country. Especially in a plural society is certainly has different law and social cultural. These differences, reflectthe differences in the conception of values or local wisdom that grows and develops in society. According to Kurnia Warman; naturally the situation and condition of society of each region will remain different. That difference, then lead to variations in their social values, including legal values as a cultural product. (Kurnia Warman: 2010). Legal pluralism in reality is related to pranata, so the arrangement can go together, but sometimes there is a conflict inside. So in pluralism situations, one can use more than one rule to rationalize and legitimize their decisions and behavior (Jazim Hamidi, et al: 2013). This condition at least shows that people have their own choice of legal systems that they believe can manage their life affairs and resolve conflicts between them. This should be a consideration for the government and legislature when formulating national law. Including in the formulation of a good legal education, will give effect to the legal awareness of the community.

\section{III.CONCLUSION}

The State of Indonesia as a country with a plurality of people who inhabit the archipelago of Indonesia, in the reality has legal fact. So that it will affect the legal culture. Legal pluralism as an approach or study is nothing but it is just a tool for the state in the process of legal formation that is more in line with the conditions of its people. It is well known that this approach also has a weak point. The presence of legal pluralism can provide perspectives on the diversity of the normative system to stakeholders. Legal certainty remains an important principle that needs to be addressed in the midst of the diverse perspectives of the legal system. So gradually the community has a high legal awareness.

\section{REFERENCE:}

Friedman, L. M. (1975). The Legal System: A Soscial Science Perspective. New York: Rusel Sage Foundation.

Griffiths, J. (1986). What is legal pluralism?. Journal of Legal Pluralism. Pp. 6-8.

Hamidi; J., Sugiharto, M. A., \& Ihsan, M. (2013). Membedah Teori-Teori Hukum Kontemporer. Malang: UB Press.

https://saepudinonline.wordpress.com/2010/11/09/sejarah-pendidikan-hukum-di-indonesia/di unduh pada tgl 14 Maret 2018.Pukul 22.00 Wita.

leip.or.id.//pluralisme-hukum-dalam-pembangunan-hukum-Indonesia, downloaded on March $23^{\text {rd }} 2018$, at 11.30 Central Indonesia Time .

Peraturan Daerah Provinsi Bali Nomor 3 tahun 2001 tentang Desa Pakraman.

Soekanto, S. (1985). Persfektif Teoritis Studi Hukum Dalam Masyarakat. Jakarta: CV. Rajawali

Tamanaha, B. Z. (2008). Understanding Legal Pluralism: past to present, local to global. Sydney Law Review 30: 375-411.

UU RI Nomor 5 Tahun 1960 Tentang Peraturan Pokok-Pokok Agraria.

Wahyuni, D. S. (2013). Pluralisme Hukum Dalam Pembangunan Hukum Indonesia;Masalah dan Tantangan ke 
The Legal Pluralism in Law Education in Indonesia

Depan, paper in $3^{\text {rd }}$ Conference of Nasional Law Philosophy Association (AFHI) in Airlangga University. Surabaya.

Warman, K. (2019). Hukum Agraria Dalam Masyarakat Majemuk, Dinamika Interaksi Hukum Adat Dan hukum Negara di Sumatera Barat. Jakarta: HUMA. 